\title{
Selective Attention: a Comparative Study on Argentine Students from Different Socioeconomic Contexts
}

\section{Mirta S. Ison, Carolina Greco, Celina Korzeniowski \\ \&}

Gabriela Morelato

Developmental and Educational Psychology Group: Human, Social and Environmental Science Institute (INCIHUSA), National Scientific and Technical Research Council (CONICET)

Psychology College, Aconcagua University, Mendoza

\section{Argentina}

Correspondence: Mirta Ison, INCIHUSA - CONICET; Av. Dr. Ruiz Leal s/n, Parque General San Martín, Post office box 131 (CP 5500), Mendoza, Argentina; e-mail: mison@mendoza-conicet.gob.ar

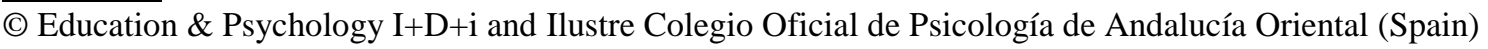




\begin{abstract}
Introduction. Attentional Efficiency (AE) is defined as the accuracy with which a child discriminates, from a group of similar stimuli, those which are identical to a model, within a certain time period. Various factors may be associated with a higher or lower AE, among which is socioeconomic context. The goals of this study were: 1) To describe argentine students`attentional efficiency according to the type of school (private-public), according to the students`age and gender and acoording to the educational and occupational level of the students`mothers; 2) To compare attentional efficiency according to the type of school (privatepublic), students`age and gender and educational and occupational level of their mothers.
\end{abstract}

Method. A comparative cross-sectional study was used. Two groups of 10-to-13-year-old students were formed: 74 from public schools (Mean 11.26; S.D. 0.93; 53\% boys and 47\% girls) and 67 students (Mean 11.49; S.D. 1.05; 54\% boys and 46\% girls) from a private schools. Type of school is categorized by Mendoza general Board of Education. Private schools are located in urban areas. Public schools are situated in peripheral areas in contexts of social vulnerability. Social vulnerability is a condition of social risk that hinders, either immediately or in the long term, the satisfaction of welfare needs, both in terms of survival and quality of life. In this kind of contexts there are lower levels of education in the families, poor working conditions and/or unemployment, families dysfunction and poor mother and child health services. All of these situations lead to unequal social conditions and decreasing opportunities for children's development.There are 10 public schools in peripheral areas and 25 private schools in urban areas at Guaymallen, Mendoza. The participants were from two schools, one from public and other from private school.

Results. The results revealed lower attentional efficiency in school children attending public schools than in those attending a private schools. No statistically-significant differences were observed in attentional efficiency in relation to the gender or age of the participating children. The students whose mothers had attained a university level of education showed a significantly higher attentional performance, in contrast with those students whose mothers had only attended primary school. In adittion, the students whose mothers were employed showed a significantly higher attentional performance in constrast with those children whose mothers 
were unemployed. Nervertheless, no statistically-significant differences were observed in attentional efficiency in relation to occupational level of qualification of students' mothers.

Conclusion: This study concurs with research showing the influence of socioeconomic context on children's attentional performance, contributing evidence on the need to adjust educational practices and cognitive interventions to boost children's academic achievements.

Keywords: attentional efficiency, socieconomic context, children, schools.

Reception: 04.16.15 Initial acceptance: 05.04.15 Final acceptance: 06.15.15

\section{Atención Selectiva: un estudio comparativo sobre los estudiantes argentinos de diferentes contextos socioeconómicos Resumen}

Introducción. La Eficacia Atencional (EA) es definida como la exactitud con la cual un niña/o discrimina estímulos iguales a un modelo, dentro de un conjunto de estímulos semejantes, en un tiempo determinado. Diversos factores pueden asociarse a una mayor o menor EA, entre ellos el contexto socieconomico. Los objetivos de este estudio fueron: 1) describir la eficacia atencional en escolares argentinos según el tipo de escuela a la cual asisten (privadapública), según la edad y el género de los escolares y según el nivel educativo y ocupacional de las madres de los escolares; 2) comparar la eficacia atencional según el tipo de escuela (privada-pública), según la edad y el género de los escolares y según el nivel educativo y ocupacional de las madres de los escolares.

Método. Se utilizó un estudio comparativo de tipo trasversal. Se conformaron dos grupos de escolares de 10 a 13 años de edad: 74 pertenecientes a escuelas públicas $(\mathrm{M}=11.26$; $\mathrm{DS}=$ $0.93 ; 53 \%$ varones y $47 \%$ niñas $)$ y 67 escolares $(M=11.49 ; \mathrm{DS}=1.05 ; 54 \%$ varones y $46 \%$ 
niñas) pertenecientes a una escuela privada. El tipo de escuela es caracterizada según la Dirección General de Escuela. Las escuelas privadas están ubicadas en zonas urbanas. Las escuelas públicas están localizadas en áreas periféricas en contextos de vulnerabilidad social. La vulnerabilidad social es una condición social de riesgo que dificulta en el presente o futuro la satisfacción del bienestar en tanto subsistencia y calidad de vida. En este tipo de contextos existen bajos niveles educativos en las familias, condiciones laborales precarias, familias disfuncionales y deficitarios servicios de salud para las madres y sus hijos. Todas estas situaciones conllevan a una condición social de desigualdad y de disminución de oportunidades para el desarrollo infantil. En Guaymallen, Mendoza, hay 10 escuelas públicas en zonas periféricas y 25 escuelas privadas. Los participantes provienen de dos escuelas, una pública y otra privada de dicha localidad.

Resultados. Los resultados indicaron una menor eficacia atencional en escolares que concurren a escuelas públicas en comparación con aquellos que asisten a una escuela privada. No se registraron diferencias estadísticamente signitivativas en eficacia atencional en relación al género o a la edad de los escolares participantes. Los escolares cuyas madres obtuvieron un nivel universitario obtuvieron un desempeño atencional significativamente superior en comparación con los escolares cuyas madres presentaron un nivel de escolaridad primaria. Además, los escolares cuyas madres eran laboralmente activas presentaron un desempeño atencional significativamente mayor en comparación con los escolares cuyas madres estaban desocupadas. Sin embargo, no se observaron diferencias significativas en el desempeño atencional de los niños en relación a la clasificación ocupacional de sus madres.

Conclusión. Este trabajo coincide con investigaciones que muestran la influencia del contexto socioeconómico sobre el desempeño atencional de los niños, aportando evidencia sobre la necesidad de adecuar las prácticas educativas e intervenciones cognitivas a fin de potenciar los logros académicos de los niños.

Palabras Clave: eficacia atencional, contexto socieconomico, nivel educativo, niños. 


\section{Introduction}

Attention may be defined as a "vertical control" mechanism whose function is to determine which stimuli perceptive resources will be directed to, by activating or inhibiting the processes involved in the processing and organization of information (Farah, 2000; Roselló i Mir, 1998). More specifically, attentional efficiency refers to the child's level of performance in selecting and sustaining attention during the period of time required by the task proposed, in accordance with what is expected for their developmental age. This involves directing and sustaining voluntary attention towards the task being performed while inhibiting possible interferences by distracting stimuli (Ison, in press; Petersen \& Posner, 2012).

Various studies have revealed that cognitive control processes such as attentional capacity, flexibility, working memory and inhibitory control are predictors of academic achievements in early and middle childhood (Blair, 2013; Davidson, Amso, Anderson \& Diamond, 2006; Garon, Bryson, \& Smith, 2008; Zelazo, \& Müeller, 2002). Furthermore, it has been proved, both in children and in adults, that the greater the attentional capacity, the greater the performance in tasks demanding cognitive control (Chang \& Burns, 2005; Matute, Sanz, Gumá, Rosselli \& Ardila, 2009; Rosselli \& Ardila, 2003). In other words, attention plays a key role in boys and girls' school performance, as it is involved in the selection and sustenance of relevant information, giving place to the manipulation of mental representations and modulating the responses to different stimuli (Betts, Mckay, Maruff, \& Anderson, 2006; Strauss, Sherman \& Spreen, 2006).

Attention as a cognitive process is not the only one that will influence students performance. There are socioambiental conditions that influence that performance. From a comprehensive approach to child psychology and as cognitive neuroscience research progresses, sufficient evidence emerges showing an association between sociocontextual conditions and the performance of cognitive processes during childhood (Hook, Lawson \& Farah, 2013). Cognitive performance may be modified by epigenetic mechanisms, suggesting that experience has a strong influence on genetic expression and the resulting cognitive performance scores (Gräff \& Mansuy, 2008; Hackman \& Farah, 2009). From this perspective, the development of the various brain regions which are responsible for cognitive and socio-emotional functioning depends on the joint action of a complex genetic program and of experience, 
which, in turn, may vary according to environmental stimulation (Rosenzweig, 2003; Noble, Houston, Kan \& Sowell, 2012).

The quality of experience will be subject to the opportunities or restrictions present in the interaction contexts in which a child develops. This will depend on the degree of access to a series of resources (both material and symbolic) and on the range of opportunities that a community may offer. Thus, the analysis of dimensions such as family composition and dynamics, habitat, human capital (basically health and education), employment, availability of labor and social assistance and social capital could allow for the setting up of gradients of socially vulnerable contexts which will have an impact, in different ways, on the child's cognitive development and functioning.

Social vulnerability is a condition of social risk that hinders, either immediately or in the long term, the satisfaction of welfare needs, both in terms of survival and quality of life (Golovanevsky, 2007). In Latin America, growing inequality and unfavorable working conditions increase the degree of vulnerability in children and their families, as they lead to unequal social conditions and decreasing opportunities for development. It is thus possible to assume that socioeconomic context may affect attentional efficiency in boys and girls, mainly due to family dysfunction, child abuse, poor mother and child health services and unfavorable schooling conditions (Matute et al., 2009).

Numerous studies have documented that those children and adolescents who grow under situations of social vulnerability show a lower performance in cognitive functioning (Farah et al., 2006; Hackman \& Farah, 2009; Hermida, Segretin, Lipina, Benarós \& Colombo, 2010; Lipina, Martelli, Vuelta, Injoque-Ricle \& Colombo, 2004; Mezzacappa, 2004; Noble \& Farah, 2013; Prats et al., 2012) and in the development of socio-affective skills (Ison, 2001, 2004; Ison \& Morelato, 2002; Ison \& Morelato, 2008; Greco \& Ison, 2014), when compared with those whose conditions for development were more favorable (Hook et al., 2013).

With regard to age, attentional performance improves during the schooling period, from the age of 8 to the age of 12 , when it reaches its maximum development, as this age period is associated with the maturation of certain areas of the central nervous system which allow for such development (Matute et al., 2009). According to gender, the cited authors point out that girls outperform boys in some of the attention and memory tests, such as tasks involv- 
ing verbal information or requiring a verbal strategy (retrieval by keywords), since these would be associated with early language development, which is predominant in girls.

Recent research reveals how certain socio-contextual factors could act as modulators between socio-cognitive-emotional development in childhood and the social vulnerability conditions. One of the factors that has been more studied is socio-economic status (SES), which is usually calculated by measuring parental education levels and occupational standing, although it encompasses much more than these two indices, including family income, parents' physical and mental health, the presence or not of both parents at home, nutrition, exposure to contaminants, differences in the characteristics of the schools the children attend, teachers' educational quality, teacher-student ratio, number of days the student has attended school during the year, availability of didactic resources at school, etc. (Evans, 2004; D'Angiulli, Lipina \& Olesinska, 2012; Farah, et al., 2006; Hackman \& Farah, 2009; Matute, et al., 2009; Najman et al., 2009; Noble et al., 2012, Tong, Baghurst, Vimpani \& McMichael, 2007).

In line with what has been expressed, specific studies on attentional performance in childhood have demonstrated that children whose parents had lower educational and occupational levels showed a lower performance in tasks requiring attentional control and alertness, as they presented greater frequency of errors and longer reaction times (Mezzacappa, 2004; Weatherholt, Harris, Burns \& Clement, 2006). Although most studies conclude that development in social vulnerability contexts is associated with low performance in tasks demanding executive control processes, other studies do not posit such a close relationship between the two. D'Angiulli, Weinberg, Grunau, Hertzman \& Grebenkov (2008) examined the relationship between SES and the neural correlates of selective attention, comparing the records of evoked potentials in a selective attention auditive task in pre-adolescents belonging to low and high SES backgrounds. They concluded that pre-adolescents from low SES backgrounds paid attention to both relevant and irrelevant information and used more executive control resources than the pre-adolescents from high SES backgrounds.

D'Angiulli, Herdman, Stapells \& Hertzman (2008) highlight that, from the point of view of developmental psychobiology, these results challenge the opinion maintaining that the fact that for a child to belong in a low SES background necessarily has a negative influence on their development. The differences in neuronal processes of children belonging to either low or high SES backgrounds do not necessarily involve a gap in performance. The 
results may be interpreted as differences in the regulation of the response to tasks demanding attentional control, which allows children to adapt to environments presenting different kinds of challenges in information processing. As the two groups of children live in very different backgrounds, they might develop self-regulation patterns depending on their experience, which may be associated with attentional selectivity and executive control processes (D’Angiulli, Weinberg, et al., 2008; Noble, Norman \& Farah, 2005).

Along similar lines, Orozco, Perinat \& Sánchez (2009) found no relationship between the performance achieved by children in a problem-solving task and the socio-economic level of families in a situation of poverty. What is more, they even detected children with high levels of performance. These authors also found that high parental expectations is the variable that is best associated with child achievement, and that maternal child-rearing practices correlate with the parental levels of expectation and child achievement. Besides, parental education and occupational level modulate students ` performance in tasks requiring executive control.

Manly, Jacobs, Touradji, Small \& Stern (2002) found that the quality of parental education predicts, to a great extent, performance in various cognitive tests. Research work carried out by Stevens, Lauinger \& Neville (2009) on children between 3 and 8 years of age indicated that the children whose mothers had low educational levels (without university experience) showed a lower performance in an auditive selective attention task than those children whose mothers had higher educational levels (at least one year of university education). The environment provides the daily practices from which the children derive experiences that enable them to progressively build different types of capacities, structures and modalities of socio-cognitive functioning to respond to the demands of the environment (Orozco, Sánchez \& Cerchiaro, 2012). In the first place, it is significant adults who provide the child with practices of behavior regulation, protection and care. From this perspective, parental educational level would be an important predictor of attention development, due to the mediating role of family interaction patterns in tasks demanding cognitive control.

\section{The present study}

In this study socioeconomic context include type of schhol, students age and gender and mother's educational and occupational level. It is expected that the parents' educational level, in conjunction with the context of the school their children attend, will have an effect on the development of attentional efficiency. Under this conceptual framework, the goals of 
this study were: 1) To describe argentine students`attentional efficiency according to the type of school (private-public), according to the students` age and gender and acoording to the educational and occupational level of the students`mothers; 2) To compare attentional efficiency according to the type of school (private-public), students`age and gender and educational and occupational level of their mothers.

This study is expected to contribute knowledge regarding the modulating role that socio-environmental factors play in children's attentional performance, with the aim of generating further evidence that may be helpful when it comes to implementing psycho-educational intervention programs and guiding public educational, health and social policies for the promotion, prevention and assistance of child mental health and education.

\section{Method}

\section{Participants}

A non-probabilistic, intentional sample was used, in which 147 students from the province of Mendoza (Argentina) participated, of both genders, aged between 10 and 13 (mean 11.37, S.D. 0.99). Out of the total number of students, six cases were detected with atypical scoring in the attentional efficiency variable, and it was determined they would not be included in the study.

Consequently, the sample was made up as follows: 141 students of both genders, of which 74 students (39 boys, 53\%, and 35 girls, 47\%), with an average age of 11.26 years (S.D. 0.93) attended public schools in socially vulnerable contexts. Social vulnerability is a condition of social risk that hinders, either immediately or in the long term, the satisfaction of welfare needs, both in terms of survival and quality of life (Golovanevsky, 2007). There are lower levels of education in the families, the parents are unemployed or are working in poor conditions, the family are dysfunction and poor mother and child health services. All of these situations lead to unequal social conditions and decreasing opportunities for childhood development. On the another hand 67 students attended a private school, of which 36 were boys (54\%) and 31, girls (46\%) with an average age of 11.49 years (S.D. 1.05).

\section{Instruments}

Test of Perception of Differences, CARAS (Original name in English: FACES) (Thurstone and Yela, 2012). This test evaluates the ability to quickly and correctly perceive 
similarities and differences by means of a visual search task. It measures selectived attention and attentional efficiency. For the purposes of this study, it is used as a tool to measure attentional efficiency. It consists of 60 graphic items ordered in series of three elements. Each series presents three basic sketches of a face, two of which are the same. The purpose of the task is to determine, in the course of three minutes, which of the faces is different and cross it out. The test has been customized for students from Mendoza aged 6-12. The test presents high internal consistence for the school population of Greater Mendoza ( $r=0.87$ ) (Ison \& Carrada, 2012). While the test permites to discriminate percentile ranges, in this study we compared the raw scores of attentional efficiency for both groups through the FACES.

Socioeconomic Report. Socioeconomic data such as parents' educational and occupational level was taken from school records and files containing data on the children's guardians. In the educational institutions selected for this study, the role of guardian is most frequently assigned to the mother. That is why this study centered on the students' mothers educational and occupational level. It is worth pointing out that the denomination of guardian is used by the school to refer to the adult who is in charge of the child, either the mother, father or another significant adult, and it does not necessarily refer to a guardianship measure. Although the intention was to have an interview with the students' guardians in order to gather the necessary information to thoroughly assess socioeconomic context, this source of information was eventually discarded as the guardians did not attend the interviews. Thus, the data existing in the school records and files was used, namely the educational level and working conditions of the students' mothers.

The database consulted for the classification of the educational levels reached was that of the Permanent Home Survey (Encuesta Permanente de Hogares), carried out by the Argentine National Institute of Statistics and Censuses (Instituto Nacional de Estadística y Censos de la República Argentina: INDEC) (INDEC, 2013). The following levels were proposed: a) No formal education/Never attended; b) Incomplete primary education; c) Incomplete high school education, d) Incomplete higher/university education, e) Complete primary education, f) Complete high school education, and g) Complete higher/university education (see Table $3)$. 
In regard to occupational level, according to Golovanevsky (2007), work is the main source of income in the household. Thus, participation in the labor market is a fundamental asset for daily subsistence. The type of job a person may secure will have implications on their living conditions. In keeping with Golovanevsky (2007), this study used, as relevant variables, a combination of the employment status and the occupational level of qualification (see Table 4).

The employment status refers to whether the mothers were employed or unemployed at the moment the school records and files were consulted. It should be noted that the term "employed" is used in reference to those mothers who have a paid job outside the home. It is widely known that women, especially those who perform their role as housewives, work 24 hours a day, whether or not they have a paid job outside the home. In this study, housewives are considered under the "unemployed" category simply because the role of housewife is not considered a paid job outside the home, not because they are considered "idle". As to occupational levels of qualification, the classification used was that proposed by the National Occupation Classification of the Institute of Statistics and Census of Argentina (INDEC), 2013. An objective description is provided of the working activity indicating the complexity of the actions involved in the process. Said classification has to do with the occupations, not with the people. It describes the degree of complexity of the work involved, not the educational level of the people who perform the work.

1) Occupations with a professional level of qualification: those involving multiple, diverse tasks performed in variable sequences, which require general and specific theoretical knowledge. For instance: executive or management positions at public institutions, social organizations or private companies; independent professional activities such as medicine, dentistry, psychology, accounting, among others (Donaire, 2005).

2) Occupations with a technical level of qualification: those usually involving multiple, diverse tasks performed in variable sequences, which require, in parallel, manipulative skills and specific theoretical knowledge. For instance: kindergarten and primary school teachers, police officers (Donaire, 2005).

3) Occupations with an operating level of qualification: those involving tasks performed in a certain variety of sequences, which require attention, promptness and manipulat- 
ive skills. However, emphasis is not placed on theoretical knowledge, as in the case of occupations with a technical qualification level. For instance: mechanics, electricians, painters, cooks, janitors, chauffeurs (Donaire, 2005).

4) Non-qualified occupations: those involving scarcely diverse tasks and the use of simple objects and instruments, or, in many cases, the worker's own body. For instance: builders, casual laborers, cardboard sellers, housemaids, gardeners. Those occupations for which it was not possible to determine a qualification but only their character as occupations, appear at the end of each category as Level of Qualification Unknown (Donaire, 2005).

The main difference between occupations with a professional and technical level of qualification and the rest is that the former require theoretical knowledge for their practice. In the case of occupations with a professional qualification level, general as well as specific theoretical knowledge is required, while occupations with a technical qualification level demand exclusively theoretical knowledge of a specific nature, in some cases coupled with certain manual skills (Donaire, 2005).

Data such as students'age and gender, were taken from school records and files containing data on the children's background. The type of schools was made according to the school categorization established by the General Board of Education. The categorization of schools is based on certain sociodemographic conditions; such as population density and spread in houses located in the school area, parental education and occupation, and rates of successful completion of primary education obtained by comparing numbers of students at first and seventh grades.

\section{Procedure}

In the first place, the goals and procedures of the study were explained to the school authorities, teaching staff, members of the psycho-pedagogical department and parents and/or adults in charge of the children. The authorization of the students' parents or guardians constituted a conditio sine quan non for the participation of the children. The free consent of the participating children was also requested. The FACES test was administered during school hours, in groups, by specialized psychologists. The classroom teacher committed herself to completing the children's school work during their absence and it was agreed that the pro- 
posed test would not be administered on days when the children had exams, were going to be taught a new topic or during special subjects (Music, Drawing and Physical Education).

\section{Design and Data analysis}

It is a comparative cross-sectional study (Hernández, Fernández \& Baptista, 2010). For the fulfillment of the first goal, descriptive statistical analyses were carried out that consist in estimating Means and Standard Desviations of students' attentional efficiency according to the type of school, according to the students`age and gender and acoording to the educational and occupational level of the students`mothers. For the fulfillment of the second goal, the Analysis of Univariate Variance (ANCOVA) test was used to compare the students' attentional efficiency according to the educational context (state- or privately-run institution) and the educational level of their mothers. Also, a T test was carried out to compare the students' attentional efficiency according to the employment status of their mothers. At the moment of performing the statistical analysis, the student's mother's educational level variable was re-categorized, giving rise to three categories: primary education, high school education and higher/university education. The three categories include both the complete and incomplete level categories. For the statistical treatment of the data, the SPSS software, version 19.5, was used. A significance level of $5 \%$ was fixed.

\section{Results}

Prior to the parametric analyses, the following was studied: the presence of atypical and lost cases, and compliance with normality assumptions of the variable under study. Analysis of the lost values was made by means of the SPSS 19.5 routine, and 3 cases (2.1\%) were identified in the mother's employment status variable. Since these cases did not exceed the $5 \%$ value, it was decided that they would be attributed to the value of the median.

Then, univariate atypical cases were analyzed using the standard rating for each variable. The values considered atypical were those which exceeded a $\mathrm{z}$ rating of 3.29 (two-tailed test, where $p<.001)$ and which were identified graphically in the box plots. Six atypical values were detected and excluded, and so the original sample of 147 students was reduced to 141, out of which 74 children made up the group of subjects studying in public school and 67 children made up the group studying in a private school. 
In order to test the sample's normality assumptions, the asymmetry (AS) and kurtosis (KS) analyses of the attentional efficiency variable were carried out, as well as a graphic inspection of the distribution of its scorings (histogram with normal curve) for each group of students. In the first group (public school), the asymmetry and kurtosis indices of the attentional efficiency variable were -1.629 and 2.721 respectively. In the second group of students (privately-managed schooling system), the indices for the same variable were AS $=-1.170$ and $\mathrm{KS}=0.804$. These values are considered optimum for the parametric analyses proposed (Gardner, 2003).

In order to address the first goal of this study, the students' attentional capacity was assessed. In the first place, the results showed that the group of students attending public schools immersed in social vulnerability contexts obtained an average of 48.73 (S.D.13.01) in the attentional efficiency variable, while the students belonging to a private school showed a higher attentional performance, with an average of 55.31 (S.D. 4.27) (see Table 1).

Table 1. Students`Attentional Efficiency according to the Type of School (Private-Public)

\begin{tabular}{|c|c|c|c|c|c|c|c|c|}
\hline & \multicolumn{4}{|c|}{ Private School $(n=67)$} & \multicolumn{4}{|c|}{ Public School $(n=74)$} \\
\hline & Mean & $\mathrm{SD}$ & AS & KS & Mean & SD & AS & $\mathrm{KS}$ \\
\hline Attentional Efficiency & 55.31 & 4.27 & -1.170 & .804 & 48.73 & 13.01 & -1.629 & 2.721 \\
\hline
\end{tabular}

Secondly, the results showed that girls (Mean 52.30, S.D. 9.70) and boys (Mean 51.47, S.D. 11.00) performed similary in attentional efficiency (see Table 2). In relation to students' age, the younger children obtained a lower attentional performance (Mean 50.60; S.D. 11.14) in contrast to the children of 11 (Mean 52.04; S.D. 9.52), 12 (Mean 52.44, S.D. 11.24) and 13 years old (Mean 52.17, S.D. 10.41) (see Table 2).

Table 2. Statistics describing Students`Attentional Efficiency according to their Age and Gender

\begin{tabular}{|c|c|c|c|c|c|c|}
\hline & \multicolumn{4}{|c|}{ Students' Age } & \multicolumn{2}{|c|}{ Students' Gender } \\
\hline & $\begin{array}{c}10 \text { years old } \\
(\mathrm{n}=30)\end{array}$ & $\begin{array}{c}11 \text { years old } \\
(\mathrm{n}=52)\end{array}$ & $\begin{array}{c}12 \text { years old } \\
(\mathrm{n}=36)\end{array}$ & $\begin{array}{c}13 \text { years old } \\
(\mathrm{n}=23)\end{array}$ & $\begin{array}{c}\text { Girls } \\
(\mathrm{n}=66)\end{array}$ & $\begin{array}{c}\text { Boys } \\
(\mathrm{n}=75)\end{array}$ \\
\hline & Mean (SD) & Mean (SD) & Mean (SD) & Mean (SD) & Mean (SD) & Mean (SD) \\
\hline $\begin{array}{l}\text { Attentional } \\
\text { Efficiency }\end{array}$ & $50.60(11.14)$ & $52.04(9.52)$ & $52.44(11.24)$ & $52.17(10.41)$ & $52.30(9.70)$ & $51.47(11.00)$ \\
\hline
\end{tabular}


Thirdly, students' attentional efficiency was described according to students mothers' educational and occupational level. The results showed that children whose mothers had reached the primary school level (Mean 50.67, S.D. 8.55; Mean 46.70, S.D. 16.15, incomplete and complete respectively) presented lower attentional performance than the students whose mothers had reached a secondary (Mean 51.50, S.D. 9.99; Mean 56.19, S.D. 4.64, incomplete and complete respectively) or university education level (Mean 56.19, S.D. 4.64; Mean 54.08, S.D. 4.51, incomplete and complete respectively) (see Table 3). It is also important to point out that the majority of the mothers $(50 \%)$ of the students attending a public school located within a context of social vulnerability have completed primary school as the maximum formal education level attained, while most of the mothers $(34.3 \%)$ of the children attending a private school have completed higher or university studies.

Table 3. Statistics describing the Students`Attentional Efficiency according the Educational Level of their Mothers

\begin{tabular}{|c|c|c|c|c|c|c|}
\hline & \multicolumn{6}{|c|}{ Mother's Educacional Level } \\
\hline & $\begin{array}{c}\text { Incomplete } \\
\text { Primary } \\
\text { School } \\
(n=6)\end{array}$ & $\begin{array}{l}\text { Complete } \\
\text { Primary } \\
\text { School } \\
(\mathrm{n}=37)\end{array}$ & $\begin{array}{l}\text { Incomplete } \\
\text { High School } \\
\quad(\mathrm{n}=20)\end{array}$ & $\begin{array}{l}\text { Complete } \\
\text { High School } \\
\quad(\mathrm{n}=66)\end{array}$ & $\begin{array}{l}\text { Incomplete } \\
\text { High- } \\
\text { er/University } \\
\text { Education } \\
(\mathrm{n}=21)\end{array}$ & $\begin{array}{c}\text { Complete } \\
\text { High- } \\
\text { er/University } \\
\text { Education } \\
(\mathrm{n}=26)\end{array}$ \\
\hline & Mean (SD) & Mean (SD) & Mean (SD) & Mean (SD) & Mean (SD) & Mean (SD) \\
\hline $\begin{array}{l}\text { Attentional } \\
\text { Efficiency }\end{array}$ & $50.67(8.55)$ & $46.70(15.16)$ & $51.50(9.99)$ & $56.19(4.64)$ & $56.19(4.64)$ & $54.08(4.51)$ \\
\hline
\end{tabular}

According to mothers' employment status the results showed that children whose mothers were employed had a higher attentional efficiency with an average of 54.50 (S.D. 5.85) while children whose mothers were unemployed had lower attentional performance with an average of 48.39 (13.60) (see Table 4). Finally, students whose mothers perform some kind of "non-qualified" job, such as domestic help or care service for the sick, obtained the lowest attentional eficiency with an avarege of 50.67 (S.D. 10.59) in comparison to children whose mothers perform an activity classified as professional (Mean 54.20, S.D. 4.30), technical (Mean 55.55, S.D. 4.93) or operating (Mean 55.62, S.D. 3.88) (see Table 4).

It's important to note that he majority of the mothers $(80.6 \%)$ of the students attending a private school are employed, that is to say, have a paid job outside the home, while most of the mothers $(64.9 \%)$ of the children attending a public school are unemployed. In relation to occupational level of qualification, most of the mothers $(37 \%)$ of the children attending a 
private school perform an activity classified as "professional", while most of the mothers $(46.2 \%)$ of the children attending a public school perform some kind of "non-qualified" job.

\section{Table 4. Statistics describing the Students`Attentional Efficiency according to the Occupational Level of their Mothers}

\begin{tabular}{|c|c|c|c|c|c|c|}
\hline & \multicolumn{2}{|c|}{ Employment Status } & \multicolumn{4}{|c|}{$\begin{array}{l}\text { Classification according to Occupational Level of Qualifica- } \\
\text { tion* }\end{array}$} \\
\hline & $\begin{array}{l}\text { Employed } \\
(\mathrm{n}=80)\end{array}$ & $\begin{array}{l}\text { Unemployed } \\
\qquad(\mathrm{n}=61)\end{array}$ & $\begin{array}{l}\text { Profession- } \\
\text { al level } \\
(\mathrm{n}=20)\end{array}$ & $\begin{array}{c}\text { Technical } \\
\text { level } \\
(n=22)\end{array}$ & $\begin{array}{c}\text { Operating } \\
\text { level } \\
(n=26)\end{array}$ & $\begin{array}{c}\text { Non-qualified } \\
\text { occupations } \\
(\mathrm{n}=12)\end{array}$ \\
\hline & Mean (SD) & Mean (SD) & Mean (SD) & Mean (SD) & Mean (SD) & Mean (SD) \\
\hline $\begin{array}{l}\text { Attentional } \\
\text { Efficiency }\end{array}$ & $54.50(5.85)$ & $48.39(13.60)$ & $54.20(4.30)$ & $55.55(4.93)$ & $55.62(3.88)$ & 50.67 (10.59) \\
\hline
\end{tabular}

* The total number of mothers for the frequency of the classification by employment status corresponds with the total number of mothers who are employed in both contexts $(n=26$ for mothers of students attending public schools and $n=54$ for mothers of students attending private schools).

Subsequently, and in order to deal with goal number two, a comparison was made between the attentional performance of the two school groups under study, controlling the effect of the gender and age co-variables. The variance analysis revealed statistically-significant differences in the attentional efficiency variable, according to the context, between the students attending a public and a private school F1,141 $=15.127, \mathrm{p}<.001, \eta 2=0.10$. No statistically-significant differences were observed in attentional efficiency in relation to the gender or age of the participating children (see Table 5). Overall, these results suggest that children's efficiency to focus and maintain attention over an extended period of time varies according to the school context, with a lower attentional performance being observed in the students attending public schools located in social vulnerability contexts (Mean 48.73; S.D. 13.97) than in the students attending a private school (Mean 55.31; S.D. 4.27).

Table 5. Analysis of Univariate Variance (ANCOVA) for Attentional Efficiency according to School Context

\begin{tabular}{lrrrrrr}
\hline & SS & $d f$ & \multicolumn{1}{l}{ MS } & F & \multicolumn{1}{l}{$p$} & $\eta^{2}$ \\
\hline & & & & & & \\
Age & 1.544 & 1 & 1.544 & .016 & .901 & .000 \\
Gender & 27.668 & 1 & 27.668 & .280 & .598 & .002 \\
School & 1494.913 & 1 & 1494.913 & 15.127 & .000 & .100 \\
\hline
\end{tabular}

Note: $\mathrm{n}=141 ; \mathrm{SS}=$ sum of squares; $\mathrm{MS}=$ mean square. 
Finally, the level of formal education of the mothers' participating students is a factor associated with children's attentional performance. The results indicated that the students' efficiency to focus and maintain attention varied significantly in relation to the educational level attained by their mothers $(\mathrm{F} 2.141=7.214, \mathrm{p}=.001, \eta 2=0.09)$. The post hoc analysis revealed that these differences were found between the students whose mothers had reached the university level (Mean 55.02, S.D. 4.641) and the students whose mothers had reached the primary school level (Mean 47.26, S.D.14.409), the former presenting a significantly higher attentional performance (see Table 6).

Table 6. Comparison of the Students' Attentional Efficiency according to their Mother's Educational Level

\begin{tabular}{|c|c|c|c|c|c|c|c|c|c|}
\hline \multirow[t]{2}{*}{$\begin{array}{l}\text { Educational Lev- } \\
\text { el }\end{array}$} & \multirow[t]{2}{*}{$\mathrm{N}$} & \multirow[t]{2}{*}{ Mean } & \multirow[t]{2}{*}{ SD } & \multicolumn{2}{|c|}{$\begin{array}{l}\text { Confidence } \\
\text { Interval 95\% }\end{array}$} & \multirow[t]{2}{*}{$d f$} & \multirow[t]{2}{*}{$\mathrm{F}$} & \multirow[t]{2}{*}{$p$} & \multirow[t]{2}{*}{$\eta^{2}$} \\
\hline & & & & $\begin{array}{l}\text { Lower } \\
\text { Limit }\end{array}$ & $\begin{array}{l}\text { Upper } \\
\text { Limit }\end{array}$ & & & & \\
\hline Primary School* & 43 & 47.26 & 14.409 & 42.82 & 51.69 & 2 & 7.214 & 0,001 & 0.09 \\
\hline High School & 51 & 52.82 & 8.892 & 50.32 & 55.32 & & & & \\
\hline $\begin{array}{l}\text { Higher/University } \\
\text { Education }\end{array}$ & 47 & 55.02 & 4.641 & 53.66 & 56.38 & & & & \\
\hline
\end{tabular}

* Multiple comparisons post hoc with the Games Howell statistic reveal statistically-significant differences between the primary school and higher/university education levels.

In addition, the results showed that children's attentional performance varied significantly in relation to the employment status of the students' mothers $(\mathrm{t}(76.99)=-3.28, p=.002$, $d=.58$ ). The results showed that the students whose mothers were employed (Mean 54.50, S.D. 5.85) presented significantly higher attentional efficiency in contrast to the students whose mothers were unemployed (Mean 48.39, S.D. 13.60) (see Table 7). Even though, no statistically-significant differences were observed in students' attentional efficiency in relation to occupational level of qualification of their mothers $\left(F(3)=2.40, p=.74, \eta^{2}=.08\right.$ ) (see Table 7).

Table 7. Comparison of the Students' Attentional Efficiency according to their Mother's Occupational Level

\begin{tabular}{|c|c|c|c|c|c|c|c|c|c|}
\hline \multirow[t]{2}{*}{ Employment Status } & \multirow[t]{2}{*}{$\mathrm{N}$} & \multirow[t]{2}{*}{ Mean } & \multirow[t]{2}{*}{$\mathrm{SD}$} & \multicolumn{2}{|c|}{$\begin{array}{l}\text { Confidence Interval } \\
95 \% \text { for the means } \\
\text { diference }\end{array}$} & \multirow[t]{2}{*}{$d f$} & \multirow[t]{2}{*}{$t$} & \multirow[t]{2}{*}{$p$} & \multirow[t]{2}{*}{$d$} \\
\hline & & & & $\begin{array}{c}\text { Lower } \\
\text { Limit } \\
\end{array}$ & $\begin{array}{l}\text { Upper } \\
\text { Limit }\end{array}$ & & & & \\
\hline Employed & 80 & 54.50 & 5.85 & -9.81 & -2.40 & 76.99 & -3.28 & .002 & .58 \\
\hline Unemployed & 61 & 48.39 & 13.60 & & & & & & \\
\hline
\end{tabular}




\begin{tabular}{|c|c|c|c|c|c|c|c|c|c|}
\hline \multirow{2}{*}{$\begin{array}{l}\text { Occupational Level of Qual- } \\
\text { ification }\end{array}$} & \multirow{2}{*}{$\mathrm{N}$} & \multirow{2}{*}{ Mean } & \multirow{2}{*}{ SD } & \multicolumn{2}{|c|}{$\begin{array}{l}\text { Confidence Interval } \\
95 \% \text { for Means }\end{array}$} & \multirow{2}{*}{$d f$} & \multirow{2}{*}{$\mathrm{F}$} & \multirow{2}{*}{$p$} & \multirow{2}{*}{$\eta^{2}$} \\
\hline & & & & $\begin{array}{l}\text { Lower } \\
\text { Limit }\end{array}$ & $\begin{array}{l}\text { Upper } \\
\text { Limit } \\
\end{array}$ & & & & \\
\hline Profesional Level & 20 & 54.20 & 4.30 & 52.19 & 56.21 & 3 & 2.40 & .074 & .08 \\
\hline Technical Level & 22 & 55.55 & 4.93 & 53.36 & 57.73 & 3 & & & \\
\hline Operating Level & 26 & 55.62 & 3.88 & 54.05 & 57.18 & 3 & & & \\
\hline Non-qualified occupations & 12 & 50.67 & 10.59 & 43.94 & 57.40 & 3 & & & \\
\hline
\end{tabular}

\section{Discussion}

One of the goals of this study was to compare attentional efficiency according to the type of school (private-public), students age and gender and educational and occupational level of their mothers. The results obtained revealed a lower attentional efficiency in the children attending public schools located in social vulnerability contexts than in the children attending a private school in an urban area. No statistically-significant differences were observed in attentional efficiency in relation to the gender or age of the participating children.

In addition, students' attentional efficiency was compared according to students mothers' educational and occupational level. The results showed that the students whose mothers had reached a university education level presented a significantly higher attentional efficiency than the students whose mothers had reached the primary school level. Similary, the students whose mothers were employed showed a significantly higher attentional performance in constrast with those children whose mothers were unemployed. Nervertheless, no statisticallysignificant differences were observed in attentional efficiency in relation to occupational level of qualification of students' mothers.

Our results are in keeping with those investigations which have documented that the children and adolescents who grow up under situations of social vulnerability show a lower performance in cognitive functioning (Farah et al., 2006; Hackman \& Farah, 2009; Hermida, Segretin, Lipina, Benarós \& Colombo, 2010; Lipina, Martelli, Vuelta, Injoque-Ricle \& Colombo, 2004; Mezzacappa, 2004; Noble \& Farah, 2013; Pratt et al., 2012) than those whose development conditions were more favorable (Hook et al., 2013).

It is likely for such difference to be due to the influence of socioeconomic context on the cognitive and socio-affective development of children. Mezzacapa (2004) maintains that the quality of the family environment is a predictor of the children's competencies in main- 
tained attention and inhibitory control. In line with what has been said, Manly et al. (2002), found that the quality of the parents' education predicts, to a great extent, their children's performance in various cognitive tests.

In this study the mother's educational and occupational level that was analyzed. Thus, our results showed that the majority of the mothers of the students who attend a public school had finished primary school, while most of the mothers of the students who attend a private school had completed higher or university studies. With respect to this, Matute et al. (2009), in a similar study, expressed that those parents with a higher level of education offer their children more intellectually stimulating environments, mainly as far as the language development is concerned. The cited authors maintain that although the parents' educational level has an effect on their children's language development, it might also influence the rest of the cognitive processes, including attention and memory. Several studies highlight the importance of the parents' education, especially the mother's, as it determines differences in the access to material and social resources (Blair, 2013; Hoff \& Tian, 2005;).

The students' mothers who have completed higher education also obtain better working positions and opportunities than the mothers who have reached the primary school level. Hence, most of the jobs performed by the mothers of the students attending a private school and who had completed university studies were occupations with a professional level of qualification such as executive or management positions at public or private institutions; independent professional activities such as medicine, dentistry, psychology, accounting, and university teaching, among others. On the other hand, the mothers of the students attending a public school and who had completed the primary school level had non-qualified occupations, and they were, for example, household maids, caregivers, cleaners. Such jobs are usually temporary and underpaid.

In addition to the parents' educational and occupational level, other aspects may influence the children's cognitive development, such as family composition and dynamics, habitat, the parents' health, cognitive stimulation at home, nutrition, exposure to contaminants in the area where they live. Also, variables such as teacher-student ratio, number of days the student has attended school during the year, the school's availability of didactic resources (Evans, 2004; D'Angiulli et al., 2012; Farah et al., 2006; Hackman \& Farah, 2009; Manly et al., 2002; 
Matute et al, 2009; Najman et al., 2009; Noble et al., 2012, Tong et al., 2007) have an impact on the various activities carried out in the classroom and may affect the quality of education.

The results make it possible to infer differences in opportunities as well as restrictions presented by the families of those students living in areas which are socially more unfavorable, which may have an influence on the children's cognitive and socio-emotional performance.

\section{Conclusions, limitations and future lines of investigation}

This piece of research is along the lines of the studies that highlight the influence of socioeconomic contexto in the child`s cognitive development, specifically over the attentional performance.

One of the limitations of this study was the reduced number of participating school children. As a consequence, the results obtained are circumscribed to the studied sample. It should also be considered that only the attentional efficiency variable was measured. A second measurement of attention should be included in future studies in order to analyze the stability of the measurement. Furthermore, it would be convenient to broaden the student's context of reference, taking into account variables such as the student's nutritional status and health, both parents' educational and occupational level, their income, family organization and dynamics, characteristics of the home and access to health care services. The inclusion of these variables will allow the creation of a social vulnerability index and the observation of cognitive development while taking into consideration specific aspects of the context of reference, within an ecological model of development. Such an approach may contribute to a greater integration between cognitive studies and socioeconomic context.

\section{Acknowledgements}

This paper has been written within the framework of the PIP- 11220100100347 project entitled Development of Socio-Cognitive Functions in Schoolchildren Living in Socially Vulnerable Conditions (Human, Social and Environmental Science Institute (INCIHUSA) - National 
Scientific and Technical Research Council (CONICET), within the research lines of the science and technology research career of CONICET in Mendoza- Argentina.

\section{References}

Betts, J., Mckay, J., Maruff, P. \& Anderson, V. (2006). The development of sustained attention in children: The effect of age and task load. Child Neuropsychology, 12, 205-221. Doi: $10.1080 / 09297040500488522$

Blair, C. (2013). Funciones ejecutivas en el salón de clase. In: Morton JB, Tremblay RE, Boivin M, Peters RDeV, Boivin M, (Eds.). Enciclopedia sobre el Desarrollo de la Primera Infancia [online]. Montreal, Quebec: Centre of Excellence for Early Childhood Development and Strategic Knowledge Cluster on Early Child Development; 17. Retrieved from http://www.enciclopedia-infantes.com/sites/default/files/textesexperts/es/2480/funciones-ejecutivas-en-el-salon-de-clase.pdf

Chang, F., \& Burns, B. (2005). Attention in preschoolers: Associations with effortful control and motivation. Child Neuropsychology, 76, 247-263. Doi 10.1111/j.14678624.2005.00842.x.

D'Angiulli A., Herdman A., Stapells D., \& Hertzman C. (2008). Children's event-related potentials of auditory selective attention vary with their socioeconomic status. Neuropsychology 3, 293-300. Doi 10.1037/0894-4105.22.3.293.

D'Angiulli, A, Lipina, S. J., \& Olesinska, A. (2012). Explicit and implicit issues in the developmental cognitive neuroscience of social inequality. Frontiers in Human Neuroscience, 6, 254-254.

D’Angiulli, A., Weinberg, J., Grunau, R., Hertzman, C., \& Grebenkov, P. (2008). Towards a cognitive science of social inequality: children's attention-related ERPs and salivary cortisol vary with their socioeconomic status. In B. C. Love, K. McRae, \& V. M. Sloutsky (Eds.), Proceedings of the 30th Cognitive Science Society Annual Meeting (pp. 211-216). Wahington, DC: Cognitive Science Society.

Davidson, M. C., Amso, D., Anderson, L. C., \& Diamond, A. (2006). Development of cognitive control and executive functions from 4-13 years: Evidence from manipulations of memory, inhibition, and task switching. Neuropsychology, 44, 2037-2078. 
Donaire, R. (Agosto, 2005). Aproximación a una caracterización social del trabajo docente, Argentina 2001. Paper presented in the $7^{\circ}$ Congreso Nacional de Estudios del Trabajo, Buenos Aires, Argentina. Retrieved from www.aset.org.ar/congresos/7/15010.pdf

Evans, G. W. (2004). The environment of childhood poverty. American Psychologist, 59(2), 77-92.

Farah, M. J. (2000). The Cognitive Neuroscience of Vision. USA: Blackwell Publishers Inc.

Farah, M. J., Shera, D. M., Savage, J. H., Betancourt, L., Giannetta, J. M., Brodsky, N. L., \& Hurt, H. (2006). Childhood poverty: Specific associations with neurocognitive development. Brain Research, 1110(1), 166-174.

Gardner, R. C. (2003). Estadística para Psicología usando SPSS para Windows. Naucalpan, México: Pearson Educación.

Garon, N., Bryson, S.E. \& Smith, I.M. (2008). Executive function in preschoolers: a review using an integrative framework. Psychological Bulletin, 134, 31-60.

Golovanevsky, L. (2007). Vulnerabilidad social: una propuesta para su medición en Argentina. Revista de Economía y Estadística, XLV(2), 53-94.

Gräff, J., \& Mansuy, I. M. (2008). Epigenetic codes in cognition and behaviour. Behavioral Brain Research, 192, 70-87.

Greco, C. \& Ison, M.S. (2014). What make you happy? Appeciating the reasons that bring happiness to argentine children living in vulnerable social contexts. Journal of LatinoLatin American Studies, 65(1), 4-18.

Hernández, R., Fernández, C., Baptista, P. (2010). Metodología de la Investigación. Fifth edition. Colombia: McGraw Hill

Hackman, D. A. \& Farah, M. J. (2009). Socioeconomic status and the developing brain. Trends in Cognitive Sciences, 13(2), 65-72. Doi:10.1016/j.tics.2008.11.003

Hermida, M. J., Segretin, M. S., Lipina, S. J., Benarós, S. \& Colombo, J. A. (2010). Abordajes neurocognitivos en el estudio de la pobreza infantil: consideraciones conceptuales y metodológicas. International Journal of Psychology and Psychological Therapy, $10(2), 205-225$.

Hoff, E. \& Tian, C. (2005). Socioeconomic status and cultural influences on language. Journal of Communication Disorders, 38(4), 271-278. doi: 10.1016/j.jcomdis.2005.02.003

Hook C.J., Lawson G.M., Farah M.J. (2013). La condición socioeconómica y el desarrollo de las funciones ejecutivas. In: Morton JB, Tremblay RE, Boivin M, Peters RDeV, Boivin M, (Eds.). Enciclopedia sobre Desenvolvimento na Primeira Infância [online]. Montreal, Quebec: Centre of Excellence for Early Childhood Development and Stra- 
tegic Knowledge Cluster on Early Child Development, 1-8. Retrieved from http://www.enciclopedia-infantes.com/documents/BlairESPxp1-

Funciones_ejecutivas.pdf

Ison, M. S. (2001). Training in social skills: An alternative technique for handling disruptive child behavior. Perceptual and Motor Skills - Psychological Reports, 88, 903 -911

Ison, M. S. \& Morelato, G. S. (2002). Contexto familiar y desarrollo de habilidades cognitivas para la resolución de problemas interpersonales en niños.PSYKHE, 11(1), 149 - 157.

Ison, M. S. (2004). Características familiares y habilidades socio-cognitivas en niños con conductas disruptivas. Revista Latinoamericana de Psicología, 36(2), 257 -268.

Ison, M. \& Morelato, G. (2008). Habilidades socio-cognitivas en niños con conductas disruptivas y víctimas de maltrato. Universitas Psychologica, 7(2), 47-57.

Ison, M. S. \& Carrada, M. (2012). Tipificación argentina del Test de Percepción de Diferencias (CARAS). In L.L Thurstone and M. Yela. Test de Percepción de Diferencias Revisado (CARAS-R) (pp.37-63). Madrid: TEA Ediciones.

Ison, M. S. (in press). Attentional capacity in children: intervention programmes for its development. In P. A. Gargiulo. Neurosciences and Psychiatry. Bridging the Differences. USA: Springer.

Lipina S.J., Martelli M.I., Vuelta B., Injoque Ricle I. \& Colombo J.A. (2004). Pobreza y desempeño ejecutivo en alumnos preescolares de la ciudad de Buenos Aires (Argentina). Interdisciplinaria, 21, 153-193.

Manly, J.J., Jacobs, D.M., Touradji, P., Small, S.A., \& Stern,Y. (2002). Reading level attenuates differences in neuropsychological test performance between African American and White elders. Journal of the International Neuropsychological Society, 8, 341348.

Matute, E., Sanz, A., Gumá, E., Roselli, M. \& Ardila, A. (2009). Influencia del nivel educativo de los padres, el tipo de escuela y el sexo en el desarrollo de la atención y la memoria. Revista Latinoamericana de Psicología, 41(2), 257 - 273.

Mezzacappa, E. (2004). Alerting, Orienting, and Executive Attention: Developmental Properties and Sociodemographic Correlates in an Epidemiological Sample of Young, Urban Children. Child Development, 75(5), 1373 - 1386.

National Institute of Statistics and Census of Argentina (Instituto Nacional de Estadística y Censos de la República Argentina) INDEC (2013). Report EPH Permanent Household Survey 2013. Retrieved from http://www.indec.gov.ar/dbindec/. 
Najman, J. M., Hayatbakhsh, M. R., Heron, M. A., Bor, W., O’Callaghan, M. J. \& Williams, G. M. (2009). The impact of episodic and chronic poverty on child cognitive development. The Journal of Pediatrics, 154(2), 284-289. doi: 10.1016/j.jpeds.2008.08.052

Noble, K. G. \& Farah, M. J. (2013). Neurocognitive consequences of socioeconomic disparities: the intersection of cognitive neuroscience and public health. Developmental Science, 16(5), 639-640. doi: 10.1111/desc.12076.

Noble, K. G., Houston, S. M., Kan, E. \& Sowell, E. R. (2012). Neural correlates of socioeconomic status in the developing human brain. Developmental Science, 154, 516-527. doi: 10.1111/j.1467-7687.2012.01147.x

Noble, K.G., Norman, M.F. \& Farah, M.J. (2005). Neurocognitive correlates of socioeconomic status in kindergarten children. Developmental Science, 8(1), 74-87. doi: 10.1111/j.1467-7687.2005.00394.x

Orozco, M., Perinat, A. \& Sánchez, H. (2009). Cognitive development and interaction context. In A. C. Bastos \& E. Prabinovich (Eds.), Living in poverty: Developmental poetics of cultural realities.Charlotte, NC: Information Age Publishing.

Orozco, M., Sánchez, H., \& Cerchiaro, E. (2012). Relación entre el desarrollo cognitivo y contextos de interacción familiar en niños que viven en sectores urbanos pobres. Universitas Psychologica, 11(2), 427-440.

Petersen S. E. \& Posner, M. I. (2012). The attention system of the human brain: 20 years after. Annual Review Neuroscience, 35, 73-89. doi: 10.1146/annurev-neuro-062111150525. Epub 2012 Apr 12.

Prats, L., Fracchia, C., Segretin, M.S., Hermida, M.J., Colombo, J.A., \& Lipina, S.J. (2012). Predictores socioambientales e individuales del desempeño en una tarea atencional con demandas de alerta, orientación y control en niños de edad preescolar. Revista Argentina de Ciencias del Comportamiento, 4, 19-31.

Rosenzweig, M. R. (2003). Effects of differential experience on the brain and behavior. Developmental Neuropsychology, 24(2-3), 523-540. doi: 10.1080/87565641.2003.9651909

Rosselló i Mir, J. (1998). Psicología de la atención. Introducción al estudio del mecanismo atencional. Madrid: Ed. Pirámide.

Rosselli, M., \& Ardila, A. (2003). The impact of culture and education on non-verbal neuropsychological measurements: A critical review. Brain and Cognition, 52(3), 326-333.

Stevens, C., Lauinger, B. \& Neville, H. (2009). Differences in the neural mechanisms of selective attention in children from different socioeconomic backgrounds: an event- 
related brain potential study. Developmental Science, 12(4), 634-646. doi: 10.1111/j.1467-7687.2009.00807.x

Strauss, E., Sherman, E. M. S., \& Spreen, O. (2006). A Compendium of Neuropsychological Tests: Administration, Norms, and Commentary. New York: Oxford University Press.

Tong. S., Baghurst. P., Vimpani, G., \& McMichael, A. (2007). Socioeconomic position, maternal IQ, home environment, and cognitive development. The Journal of Pediatrics, 151(3), 284-288.

Weatherholt, T., Harris, R., Burns, B., \& Clement, C. (2006). Analysis of attention and analogical reasoning in children of poverty. Applied Developmental Psychology, 27, 125135.

Zelazo, P. D., \& Müeller, U. (2002). Executive function in typical and atypical development. Oxford, UK: Blackwell Publishers. 
Mirta S. Ison et al.

[This page intentionally left blank] 